\title{
The IMPACT OF A PERformant E-SHIP FRAMEWORK ON ECONOMIC DEVELOPMENT
}

\author{
ZIRRA, D.
}

Abstract: In any type of economy, the entrepreneurial activity makes an important contribution to stimulate regional development and competitiveness. But, the performance of small and medium size enterprises (SMEs) depends on the quality of economic environment and a specific assistance accorded by the public sector, consisting in a wide array of interventions like granting funds for investments, getting information and technologies, access to conciliation and external advice, improving transports and communication infrastructure, services for training and technology transfer, etc. The entrepreneurship (E-ship) represents phenomena which can create and exchange value through identifying the best opportunities offered by the market in resources changes, innovation, etc. For these reasons, in a very perturbing and unfriendly economy for SMEs, it is very important to create a stable and performing entrepreneurship framework and also an extended and well functional network for SMEs, in order to stimulate a sustainable economic development.

Key words: entrepreneurial activity, SME, entrepreneurship, framework
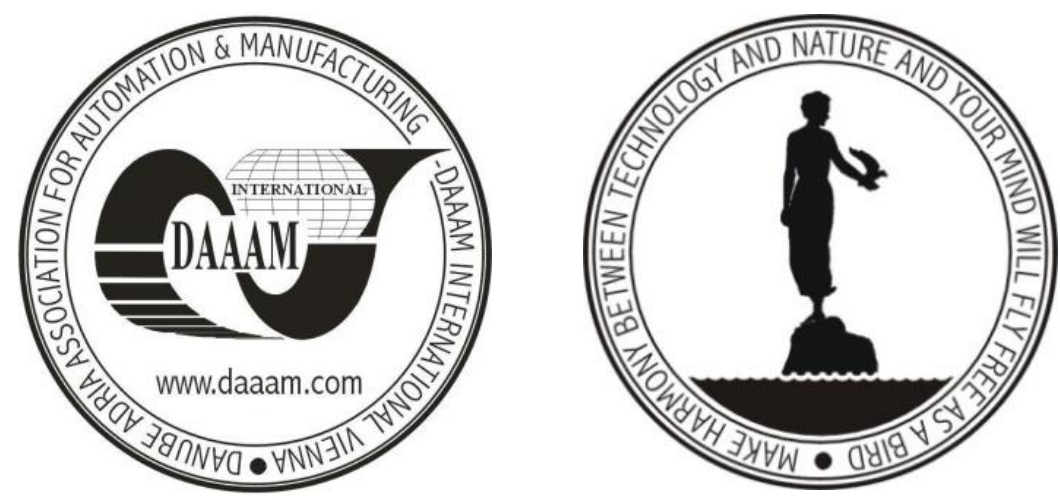

Authors' data: Univ. Prof. Zirra, D[aniela], Romanian-American University, Expoziţiei Blv. 1B, 012101, Bucharest, Romania, daniela.zirra@gmail.com

This Publication has to be referred as: Zirra, D[aniela] (2010). The Impact of a Performant E-Ship Framework on Economic Development, Chapter 66 in DAAAM International Scientific Book 2010, pp. 767-778, B. Katalinic (Ed.), Published by DAAAM International, ISBN 978-3-901509-74-2, ISSN 1726-9687, Vienna, Austria DOI: $10.2507 /$ daaam.scibook.2010.66 


\section{Introduction}

In Contemporary Economy, named Dynamically Competitive Era or Knowledge and Skill-based Economy, new firms creation is an accelerated and a continuous process. According to the principles of the new economy, E-ship performance represents the key for a sustainable economic development and competitiveness.

In the beginning of this paper it should notice that today, the economic and social environment characteristics are permanent changing, rapid evolution in technologies and market conditions, an accentuate incertitude and risk for economic activities.

In actual circumstances of economic evolution, it is more and more difficult to realise economic performance and to evaluate how a public decision can stimulate entrepreneurial activity, new firms creation, the ambitions of entrepreneurs and managers to create wealth.

Also, it is very important to have all the elements for measuring the effects of allocating funds to sustain economic development, to increase the dynamic of companies' activity and to improve the characteristics of business environment, with all the consequences involved.

For this reason, E-ship, as phenomena that create and exchange value (SCADPlus, 2008), need a specific and complex framework which is capable to stimulate and support the economic performances of firms in the new era.

At international level there are various models of E-ship framework, but they need to be improved and updated such as the requirements and the dynamic of internal and international environment are asking.

In these conditions, an E-ship framework must provide flexible and updated services, especially for the new born firms.

\section{E-ship activity and SMEs in contemporary economy}

The restructuring analysts of European economies (Haar et al., 2007) have identified two significant trends of environment evolution in the coming decade:

- Accelerated technological development, especially in ICT, biotechnology, nanotechnology and materials technology, which generate an accentuate development of multiple or interdisciplinary technologies.

- Continuous liberalization of international trade which enforce the integration of more and more countries into global economy.

In theses circumstances, the direct effects of mentioned trends are increasing weight of interdisciplinary technologies applied in economic and social activities, a rapid global economy development and also generate an increasing dynamic and complexity of environment changing.

This is one of the reasons because the Economic Development Programmes cofinanced by cohesion policy at European level must target resources on three priorities (Communication to the Spring European Council, 2005): 
- Increasing the attractiveness of Member States regions and cities by improving accessibility, ensuring adequate quality structure and level of services and preserving environmental potential.

- Encouraging innovation, entrepreneurship and development of knowledgebased economy by creating or extending research and innovation capacities, on one side, and including new information and communication technologies, on the other side.

- Creating more and better jobs for attracting more people into employment or entrepreneurial activities, improving adaptability of workers and enterprises and increasing investments in developing and quality growing of human capital.

But, we have to mention that there exist a close link between the dynamic of SMEs activity and entrepreneurship and the cost of starting a business or the quality of governance, including here rule and law, control of corruption, political stability, regulatory policy and government effectiveness, the accountability, etc.

In the same time, it couldn't be ignored the positive impact of e-registration on the dynamic of new firm creation. For example in 2003-2005 the lowest entry rate, around 5\%, was calculated for the regions with the highest cost of starting a business. The entry rate is increasing from $5 \%$ or less in regions with a low quality of governance to $15 \%$ or more in the regions with high quality of governance (Klapper \& Quesada, 2007).

New firms creation depend essentially of political, institutional and tax reform. Considering this, the factors with a strong influence on new firm creation could be classified in policies, institutions and tax systems, specific for each country. As indicators for measuring the dynamic of new businesses creation or entrepreneurial activity it could be use (Klapper et. al, 2007):

- Business entry (AER - Average Entry Rates);

- Density rate (ABD - Average Business Density).

We can notice also many changing of how the entrepreneurship in define (Klapper et. al, 2007). For example, in the beginning of 1900 Schumpeter said that entrepreneurship is the assumption of risk and responsibility in designing and implementing a business strategy or starting a business.

For the World Bank specialists, entrepreneurship is the activities of an individual or a group aimed to initiating economic activities in the formal sector under a legal form of business.

The unit of measurement of entrepreneurship is any economic unit of the formal sector incorporated as a legal entity and registered in a public registry, which is capable, in its own right, of incurring liabilities and of engaging in economic activities and transactions with other entities.

In the same time, we cannot ignore the important role played by the informal sector, named also "grey economy" or even "shadow economy", for economic development, in many regions.

The weight of informal sector is bigger in less developed regions (characterised by political and institutional instability and a chaotic tax system) and lower in 
Zirra, D.: The Impact of a Performant E-Ship Framework on Economic Development developed regions as United States of America or Western Europe Developed countries.

Commission of the European Communities (2003) is defining entrepreneurship as the mind set and process to create and develop economic activity by blending risktaking, creativity and/or innovation with sound management, within a new or an existing organisation.

This is a Top-Down Approach, same as Schumpeter's definition, elaborated in a philosophical perspective, with little concern for measuring the economic performance of SMEs activity.

The Bottom-Up Approach definitions for entrepreneurship (E-ship) bases itself on the measurable characteristics that have commonly been used at national or policy level, in practice, to measure E-ship (Ahmad \& Seymour, 2008).

OECD (Organization for Economic Cooperation and Development) has settled an extended procedure for measuring the dynamic and the quality of entrepreneurship (E-ship) and entrepreneurial activity.

For this purpose it is necessary to define some specific indicators (Table 1.) which describes in a new manner the signification of the elements used in such evaluations (OECD, 2007).

\begin{tabular}{|l|l|l|}
\hline No & E-ship Indicators & Definition \\
\hline 1. & The entrepreneur & $\begin{array}{l}\text { The person who creates and exchanges value } \\
\text { through the identification and employment of } \\
\text { changes in resources, opportunities and/or } \\
\text { innovation }\end{array}$ \\
\hline 2. & E-ship & $\begin{array}{l}\text { The phenomena associated with the mindset, } \\
\text { planning and activities that create and exchange } \\
\text { value through the identification and employment } \\
\text { of changes in resources, opportunities and/or } \\
\text { innovation }\end{array}$ \\
\hline 3. & Entrepreneurial activity & $\begin{array}{l}\text { The enterprising human action associated with the } \\
\text { creation and exchange of value through the } \\
\text { identification and employment of changes in } \\
\text { resources, opportunities and/or innovation }\end{array}$ \\
\hline
\end{tabular}

Tab. 1. OECD E-ship Indicators Project - Definitions (Source: OECD)

The quality and the dynamic of SMEs activity (SCADPlus, 2008) are strongly influenced by many factors.

But, the mainly characteristics of them are:

- Very diverse (dimension, interests, activities, new firms, rapid growing gazelles, etc.), with various and different needs.

- Make an important contribution to job creation, increasing competitiveness of national economies, stimulate regional development, prosperity, cohesion and economic growth.

- Disadvantaged on both financial and labour market. 
- Very numerous (for example in EU there are 23 millions SMEs).

\begin{tabular}{|l|l|l|l|l|}
\hline No & $\begin{array}{l}\text { Type of } \\
\text { Enterprise }\end{array}$ & $\begin{array}{l}\text { Employees } \\
\text { (persons) }\end{array}$ & $\begin{array}{l}\text { Annual turnover } \\
\text { (million euro) }\end{array}$ & $\begin{array}{l}\text { Annual balance- } \\
\text { sheet (million } \\
\text { euro) }\end{array}$ \\
\hline 1. & $\begin{array}{l}\text { Medium-sized } \\
\text { enterprise }\end{array}$ & Fewer than 250 & Does not exceed 50 & $\begin{array}{l}\text { Does not exceed } \\
43\end{array}$ \\
\hline 2. & $\begin{array}{l}\text { Small-sized } \\
\text { enterprise }\end{array}$ & Fewer than 50 & Does not exceed 10 & $\begin{array}{l}\text { Does not exceed } \\
10\end{array}$ \\
\hline 3. & Micro-enterprise & Fewer than 10 & Does not exceed 2 & Does not exceed 2 \\
\hline
\end{tabular}

Tab. 2. Types of Enterprises (Source: SCADPlus)

Another definition, based on the type of relation with other enterprises (speaking about percentage interest in capital, the right to exercise a dominant influence or voting rights) is distinguished three categories of enterprises (Table 3.).

\begin{tabular}{|l|l|l|l|l|l|}
\hline No & $\begin{array}{l}\text { Type of an } \\
\text { Enterprise }\end{array}$ & $\begin{array}{l}\text { Holding in } \\
\text { other } \\
\text { enterprises } \\
(\%)\end{array}$ & $\begin{array}{l}\text { Owned by } \\
\text { other } \\
\text { organisations } \\
(\%)\end{array}$ & $\begin{array}{l}\text { Draw up } \\
\text { consolidated } \\
\text { accounts }\end{array}$ & $\begin{array}{l}\text { Included in } \\
\text { the accounts } \\
\text { of an other } \\
\text { enterprise }\end{array}$ \\
\hline 1. & $\begin{array}{l}\text { Autonomous } \\
\text { enterprise-the } \\
\text { most common }\end{array}$ & $\begin{array}{l}\text { Does not } 25 \text { or } \\
\text { more }\end{array}$ & $\begin{array}{l}\text { Are not } 25 \\
\text { or more }\end{array}$ & No & No \\
\hline 2. & $\begin{array}{l}\text { Partner } \\
\text { enterprise- } \\
\text { establishing } \\
\text { major financial } \\
\text { partnerships } \\
\text { with others }\end{array}$ & $\begin{array}{l}\text { Are holding } \\
25 \text { to } 50\end{array}$ & $\begin{array}{l}\text { The other } \\
\text { enterprise } \\
\text { has } 25 \text { to } 50 \\
\text { in the } \\
\text { applicant } \\
\text { enterprise }\end{array}$ & No & No \\
\hline 3. & $\begin{array}{l}\text { Linked } \\
\text { enterprise }\end{array}$ & $\begin{array}{l}\text { An economic situation of enterprises which through direct or } \\
\text { indirect control of the majority of the capital or voting rights, } \\
\text { or through to ability to exercise a dominant influence to an } \\
\text { enterprise. }\end{array}$ \\
\hline
\end{tabular}

Tab. 3. Categories of Enterprises (Source: SCADPlus)

\section{The goal of supporting and stimulating E-ship}

The general aim of business support policies in EU industrialized areas is to increase competitiveness through various kinds of interventions (European Committee, 2007), especially for SMEs development, such as:

- Providing training, financial, information, conciliation and business services.

- Granting funds for investments and high technology transfer.

- Improving communication and transport infrastructure. 
We have to mention again that one of the key for a sustainable economic performance is to increase the competitiveness of SMEs and the dynamic of E-ship (Klapper et. al., 2007).

For example, if the goal of government is to increase the flexibility and adaptability of workforce on management level, than the place of an E-ship stimulating policy is: INPUT - state subsidy for SMEs human resources development in business management; COMPONENT - Increasing E-ship; TARGET - Increasing workers quality (abilities and skills); GOAL - Increase the flexibility and adaptability of workforce on management level, with direct effects on economic performance.

In the new era, it can be notice that we are going towards an entrepreneurial society. In these conditions, if the goal of an organisation is to increase competitiveness or to maintain it at a high level, the modern management must be in principle entrepreneurial, for all kind of firms, including micro, small and medium too (SMEs).

This requirement is more necessary in a very dynamic, aggressive and competitive environment.

In this direction, if we are referring on the managerial team of a company, it is often used the concept of dynamic abilities, which could be classified in three categories (Teece, 2007), such as:

- Ability for identifying the new market opportunities, like technological, investments, informational, commercial, financial, etc. and the risks or the potential sources of risks from the economic and social environment.

- Capacity of a correct quantification or measuring the opportunities, risks and trends of a complex and continuous changing economy.

- Skills to catch on the opportunities and to transform them in sustainable business or in real factors for enhance company performances, through reengineering the assets of the organisation and the structure of its activities.

It must be noticed that the public strategies devoted to stimulate SMEs development must be based on correct, in time and relevant information.

All of these conditions are necessary to give the opportunity and to create a technical support for all interested decision makers for a better design, implement and evaluate the effectiveness of resources allocated and used to support SMEs.

\begin{tabular}{|l|l|l|}
\hline $\begin{array}{l}\mathrm{N} \\
\mathrm{O}\end{array}$ & Influence factors & Description \\
\hline 1. & Data availability & $\begin{array}{l}\text { Not compiling data about new entry business or } \\
\text { collecting data but not processing them }\end{array}$ \\
\hline 2. & Data "purity" & $\begin{array}{l}\text { Legal or institutional reforms which change the rules } \\
\text { for registration firms or the status of the firms }\end{array}$ \\
\hline 3. & $\begin{array}{l}\text { Limitations regarding } \\
\text { data on firm closures }\end{array}$ & $\begin{array}{l}\text { Not in all countries exists requirements for reporting } \\
\text { the closure of the businesses }\end{array}$ \\
\hline 4. & $\begin{array}{l}\text { The existence of "shell" } \\
\text { corporations }\end{array}$ & $\begin{array}{l}\text { Created only for tax purpose, without being active } \\
\text { businesses }\end{array}$ \\
\hline
\end{tabular}

Tab. 4. Influence factors on gathering and processing data 
But, having the information could be a difficult process (Klapper et. al., 2007). We could outline here many influence factors with a strong impact on the quality of gathering and processing data (Table 4.).

In the same time, we have to observe that having correct and relevant information for a better design, implement and evaluate the impact of the public support action for SMEs is not an easy aspect because not in all situations/regions exists a high quality process of gathering and processing data (unfortunately, in this category we can include Romania too).

\section{An effective e-ship framework for a sustainable economic development}

Based on the results of our research, in a project for entrepreneurial and managerial skills development, which promote the development of E-ship through increasing the quality of all level management for industrial sector, we found that new firms creation depends essentially on policies, institutions and tax systems, specific for each country.

Based on WB Study, using data available from 84 countries, we can appreciate that the highest ABD per 1,000 active people, by region, in 2003-2005 is registered in Industrialized Countries (64.23\%) and the lowest in Asia (1.57\%).

The highest AER, by region, in 2003-2005, using data from 82 countries is found also in Industrialized Countries (10.24\%) and the lowest in Asia (6.7\%). In Romania, ABD is evaluating ascendant in the last 2-3 years, but the indicator is still 2.5 less than EU media.

So, the propagate goal of the project, is to create a network between business and high education, for a better evolution of the specialists supply for managerial activities in Romania, using the infrastructure and the experience of all the organisations involved in the project.

Into a dynamic business environment, considering here the rapid technological, economic, social and political changing, SMEs development is a very difficult and complex process, but with many benefits, including human resources development, social cohesion, economic growth, increasing employment, a better flexibility and adaptability of individuals and organizations, competitiveness of national economies, etc.

Also, we have to mention the close correlations between a stable and performing entrepreneurship framework and long-term company performance.

This is the reason of the central position in economic development strategies and the importance accorded to E-ship in present day economy, not only in developing countries, but in highest developed regions too. OECD has already elaborated a Demand and Supply Side Model of E-ship Framework (Ahmad \& Hoffman, 2008).

We appreciate that an adapted Model of this modern concept of the E-ship framework could be represented as in Figure 1.

E-ship meaning in modern economy is to offer the basis for the healthy circumstances of increasing and stimulating SMEs sustainable development. 


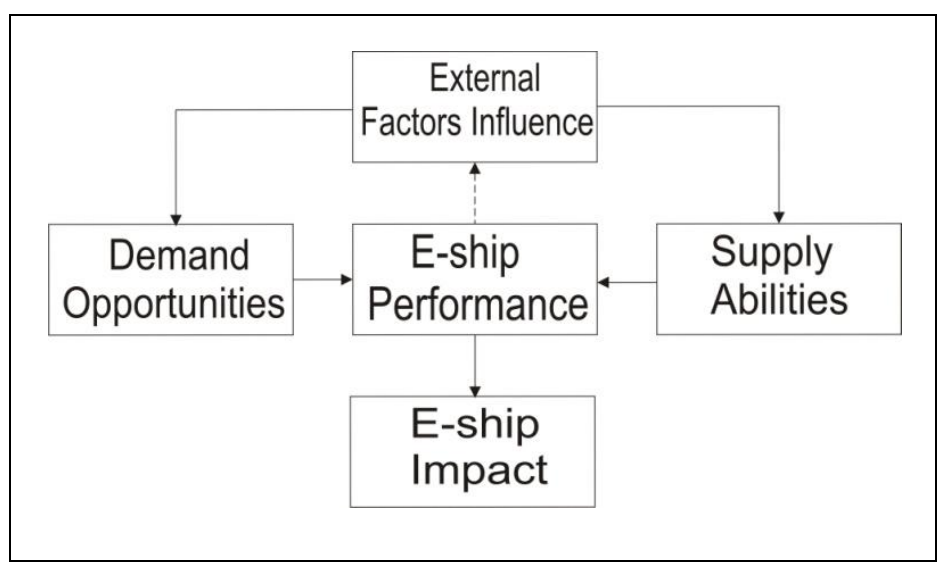

Fig. 1. E-ship Framework Model

E-ship meaning in modern economy is to offer the basis for the healthy circumstances of increasing and stimulating SMEs sustainable development.

In actual stage, without an entrepreneurial education and culture, continuous learning abilities and skills it is very difficult to realise positive effects for business performances and SMEs environment.

The elements with a direct influence on E-ship performance, and as a propagate effect with a strong influence on business performances, are:

- External Factors Influence (EFI): individual incentives, culture and motivation, education system, infrastructure, framework conditions.

- Demand Opportunities (DO): technological transfer, R\&D, communication, market access conditions, competition.

- Supply Abilities (SA): financial capital, business angel, venture capital, social capital, the quality of human capital.

All the three elements mentioned above represents the key factors which could be named the group of determinants for E-ship Performance (E-SP) and E-ship Impact (E-SI).

In the same time, we cannot ignore that E-SP have an indirect influence on EFI, which is changing periodically because of economic and social conditions, in continuous changing and evolution.

As examples for the elements which represent criteria for appreciation the ESP and E-SI, included also in the adapted Model, we can mention:

- E-SP: the rhythm of firm creation, business density, self-employment, new business survival, high growth firms.

- E-SI: poverty reduction, job creation ratio, productivity growth, economic growth, increasing of firm size.

The elements with a very strong influence on business performance are extremely diverse (OECD, 2007). For this reasons it is difficult to mark them out into distinguished categories.

According to the Statistical Business Registers (based on Administrative Registers), E-ship is the effort made to initiate an economic activity in the formal sector.

The OECD/Eurostat Approach is to create a framework for Business Demography Statistics. This approach is very important because it gives us the 
opportunity to create more effective strategies to stimulate and support new firm creation and economic performance of existing firms.

\section{How can we improve SMEs Development?}

SMEs have a significant impact on European Union economy and cohesion. For this reason they deserve a major attention and a special assistance, to stimulate SMEs sustainable development, so they could (European Portal for SMEs, 2008):

- Create more new and better jobs.

- Expand theirs product ranges, markets (internal and also international) and turnover.

- Grow more rapidly the business to a much larger size.

- Access to and produce innovation, which represents the most important key for growth and sustainable development in knowledge-based economy.

- Promote key areas for the future, like eco-innovation and increase the benefits of eco-efficiency.

We can resume all the elements mentioned above in a single word, respectively SMEs competitiveness. EU Portal for SMEs is mentioning different support directions for increasing SMEs competitiveness. Some examples of these are figured in Table 5.

\begin{tabular}{|l|l|}
\hline No & Decisions to stimulate SMEs competitiveness \\
\hline 1. & Easy access to public procurement markets \\
\hline 2. & Promoting international activities \\
\hline 3. & Recruiting high quality employees \\
\hline 4. & Increasing language skills \\
\hline 5. & $\begin{array}{l}\text { Developing co-operation between educational environment and SMEs } \\
\text { for vocational training }\end{array}$ \\
\hline 6. & $\begin{array}{l}\text { Including SMEs in Lifelong Learning programmes for a greater social } \\
\text { cohesion }\end{array}$ \\
\hline 7. & $\begin{array}{l}\text { Increasing social responsibility of the business running manner for } \\
\text { SMEs managers or for entrepreneurs }\end{array}$ \\
\hline 8. & Promoting environmentally sustainable activities \\
\hline 9. & $\begin{array}{l}\text { Using a tax system which stimulate investments, increase invested or } \\
\text { re-invested profit to grow the business }\end{array}$ \\
\hline 10. & $\begin{array}{l}\text { Support for acting and developing specific skills in a dynamic e- } \\
\text { economy to respond in a proper manner to global challenges }\end{array}$ \\
\hline
\end{tabular}

Tab. 5. Support directions for increasing SMEs competitiveness (Source: European Portal for SMEs, 2008)

But, a real effective policy, programme or strategy for SMEs must be based on correct and relevant information (Klapper et al., 2007). For example, we settle that one of the key factors for a sustainable economic development is to increase the dynamic of entrepreneurship. 
Zirra, D.: The Impact of a Performant E-Ship Framework on Economic Development

If we are considering that the goal of the government is to reduce poverty, than the place of an E-ship stimulating policy is underlined in Table 6.

\begin{tabular}{|c|c|c|c|c|c|}
\hline \multirow{2}{*}{$\begin{array}{l}\text { Key } \\
\text { Elements }\end{array}$} & \multirow[t]{2}{*}{ Specification } & \multicolumn{2}{|c|}{ Intermediate indicators } & \multicolumn{2}{|c|}{ Final indicators } \\
\hline & & $\begin{array}{l}\text { Input } \\
\text { indicator }\end{array}$ & $\begin{array}{l}\text { Output } \\
\text { indicator }\end{array}$ & $\begin{array}{l}\text { Outcome } \\
\text { indicator }\end{array}$ & $\begin{array}{l}\text { Impact } \\
\text { indicator }\end{array}$ \\
\hline Input & $\begin{array}{l}\text { State subsidy } \\
\text { for SMEs } \\
\text { investments }\end{array}$ & $\begin{array}{l}\text { Provide } 200 \mathrm{M} \\
\text { EUR public } \\
\text { funds for } \\
\text { entrepreneurs }\end{array}$ & & & \\
\hline $\begin{array}{l}\text { Compo- } \\
\text { nent }\end{array}$ & $\begin{array}{l}\text { Increasing E- } \\
\text { ship }\end{array}$ & & $\begin{array}{l}\text { Increase } \\
\text { entry rate } \\
\text { by } 10 \%\end{array}$ & & \\
\hline Target & $\begin{array}{l}\text { Increase } \\
\text { employment }\end{array}$ & & & $\begin{array}{l}\text { Reduce } \\
\text { unemploy } \\
\text { ment by } \\
4 \%\end{array}$ & \\
\hline Goal & $\begin{array}{l}\text { Reduce } \\
\text { poverty }\end{array}$ & & & & $\begin{array}{l}\text { Reduce } \\
\text { population } \\
\text { under } \\
\text { poverty } \\
\text { line by 3\% }\end{array}$ \\
\hline
\end{tabular}

Tab. 6. Government Strategy for Reducing Poverty (Source: WB, Development Research Group, Finance and Private Sector Team)

\section{What is the next step?}

E-ship activity and SMEs performance, with all the benefits involved, including growth and cohesion is a very complex process. Without entrepreneurial education and culture it is very difficult to obtain positive effects for SMEs environment. E-ship meaning is to offer the basis for the healthy circumstances of increasing and stimulating SMEs sustainable development (Ahmad \& Hoffman, 2008).

In the same time, it is very important to create an extended and very well functional network and institutional framework for SMEs. At European level, exist already The Enterprise Europe Network. This entity represents over 500 organisations in Europe and beyond, formed by Euro Info Centres (EIC), Innovation Relay Centres (IRC), European Business and Innovation Centres (BIC-EBN) and National Contact Point (NCPs). These organisations are providing very high quality integrated services to SMEs, like:

- Legislation;

- Programmes;

- Business partner searching;

- Co-operation data basses;

- Information and promoting materials; 
- Events about technology and know-how transfer;

- Education and training;

- Information on taxes, registration, public procurement, funding and employment law, etc.

All this measures are included in Gate2 Growth programme (Commission of the European Communities, 2003), supported by European Commission to:

- Support innovative entrepreneurs.

- Foster networking and the exchange of experience and good practice at European Level.

But, we should take into account that support policies for SMEs must be adapted to the particular conditions of each region and especially to the needs of these firms. It is very important also to support RTD activities in SMEs, because for them is difficult to access this kind of services.

How to do it? There are two ways to help SMEs in this direction.

The first method is through establishing poles of excellence by bringing together high technology SMEs around technological and research institutions.

The second technique means to develop and create clusters around large companies (Community strategic guidelines 2007-2013, 2007).

\section{Conclusion}

Yet, taking into account the evolution of science and technologies, the continuous changing of business environment, building an effective E-ship framework represents a permanent challenge and an opportunity to be partner in a continuous process dedicated to stimulate E-ship and to improve SMEs performances in order to support competitiveness, research and innovation capacity, more and better jobs creation, high quality of business environment, adaptability of workers and enterprises, increasing investments and development of knowledge-based economy. In these conditions, the main important requirements for a high performance of national economies are: the E-ship services must be permanent updated based on the most relevant, complete and correct information; a continuous process of developing entrepreneurial abilities and skills and also more collaborative projects between firms, universities and public sector.

All the policies dedicated to support SMEs development and competitiveness imply a significant and diverse volume of resources and the involving of social partners on large scale, also on regional and national level, for stimulating innovation, human resources development, including here entrepreneurial education too. The final aim of all of these efforts is to increase competitiveness of individuals, firms, and national economies for a healthy and sustainable economic development.

In conclusion, we should mention that the Cohesion Policy of European Union has an important macroeconomic impact, especially for the developing regions, and multiplying positive effects for the EU as a whole. Romania is a part of this process and we cannot ignore that we have a lot of things to do to catch up the developed countries, with excellent results in stimulating E-ship. 
Zirra, D.: The Impact of a Performant E-Ship Framework on Economic Development

\section{References}

Ahmad, Nadim, and Seymour Richard G. (2008), Defining Entrepreneurial Activity: Frameworks for Data Collection, OECD Statistics Working Papers, No. 2, OECD Publishing. doi: 10.1787/243160627270, JT03239191, p.5, Available from: $\quad$ http://fiordiliji.sourceoecd.org/vl=4609151/cl=48/nw=1/rpsv/cgibin/wppdf?file=5kzn93rmcg7l.pdf, Accessed on: 2009-05-12

Haahr, J. H.; Hansen, M. E. \& Andersen, T. (2007). Restructuring in Europe. The Anticipation of Labour Market Effects, p. 103, Available from: http://www.jens-henrik-haahr.dk/pdf/restructuring-to-web.pdf, Accessed on: 2009-06-02

Klapper, L. \& Quesada, M. D. (2007), Entrepreneurship - New Data on Business Creation and How to Promote It, The World Bank Group Note Number 316: Financial and Private Sector Development vice Presidency, p. 3, Available from:

http://rru.worldbank.org/documents/publicpolicyjournal/316Klapper_Delgado. pdf, Accessed on: 2009-05-28

Klapper, L.; Amit, R.; Guillén, M. F. \& Quesada, M. D. (August 2007), Entrepreneurship and Firm Formation across Countries, World Bank Policy Research Working Paper 4313. World Bank, Development Research Group, Finance and Private Sector Team, pp. 2-15, Available from: http://wwwmanagement.wharton.upenn.edu/guillen/8_07_docs/Entrep\%20Firm\%20Forma tion\%20Word\%20Bank\%204313.pdf, Accessed on: 2009-05-20

Teece, D. J. (2007), The role of managers, entrepreneurs and the literati in enterprise performance and economic growth. International Journal of Technological, Learning, Innovation and Development, Vol. 1, No 1, August 2007, pp. 48-61, ISSN 1753-1950

*** http://ec.europa.eu/enterprise/sme/competitive_en.htm, European Portal for SMEs (2008), Making SMEs more competitive, Accessed on: 07.03.2008

*** http://ec.europa.eu/enterprise/sme/support_en.htm, European Portal for SMEs (2008), Support services across Europe, Accessed on: 07.03.2008.

*** http://ec.europa.eu/invest-in-research/, Commission of the European Communities (January 2003), Green Paper Entrepreneurship in Europe, COM (2003) 27, p. 6, Accessed on: 28.03.2008

*** http://europa.eu/scadplus, Activities of the EU (2008), SCADPlus: A modern policy for SMEs, Accessed on: 2008-03-05

*** http://europa.eu/scadplus/leg/en/cha/c11325.htm, Communication to the Spring European Council (2005), Working together for growth and jobs - a new start for the Lisbon Strategy, COM (2005) 24, Accessed on: 2008-03-10

*** http://evalsed.info, European Committee (2007), Evaluating Socio Economic

Development, Sourcebook 1: Themes and Policy Areas Enterprise Policy, Accessed on: 2008-03-12

*** http://oecd.org/statistics/industry-services/entrepreneurship, OECD Entrepreneurship Indicators Project: Overview (2007), World Bank Seminar on Entrepreneurship and Development, Washington D.C., Accessed on: 2008-0309 